\title{
An ailing agency
}

\section{Public health needs strong advocacy within government - and Congress should make sure that the US Centers for Disease Control and Prevention continues to provide it.}

$1 / 2$ ight now, we are hard at work doing what we do best - protecting people's health whenever, wherever and however we are needed. For that $\mathrm{I}$, and people around the world, are most grateful." This is what Julie Gerberding, the director of the US Centers for Disease Control and Prevention (CDC), wrote in an e-mail message to employees last week; it was subsequently reprinted in the Atlanta Journal-Constitution.

Many of us do indeed have cause to be grateful for the work of the CDC. The federal agency, which started in 1946 as a small office to investigate malaria, now has around 9,000 staff and is dedicated to improving all aspects of public health in the United States. When members of the public are concerned about what vaccinations to give their children, they turn to the CDC for advice. When local health departments need guidance on the spread of HIV, they too look to the Atlanta-based agency.

Outside the United States, the CDC enjoys a hard-won reputation for its knowledge of infectious disease. Take, for example, its unparalleled 121 Cities programme for monitoring influenza, as part of which epidemiologists collect weekly figures on the number of influenza deaths from (as it happens) 122 US metropolitan areas. The programme, which can highlight a particularly pernicious flu season at its outset, is unmatched elsewhere in the world.

But some of the people who respect and rely on the CDC are now expressing worries about its own state of health. Some of those concerns are being expressed at the very roots of the agency itself, by the dedicated public-health workers on whose reputation it was built. It was the Atlanta Journal-Constitution's reporting of these concerns that prompted Gerberding's e-mail retort.

The complainants allege that good science at the agency is being hampered by bureaucracy and mismanagement. The problems have arisen in part as the result of a reorganization instigated by Gerberding in 2003, and some officials contend that they are being exacerbated by the Bush administration's efforts to exert political influence over the CDC. Some very senior people are leaving; others say they are staying only until they can collect a pension (see page 250).

Some of these complaints may well have been provoked by any kind of organizational revamp. But when five former directors of the CDC feel compelled to intervene, as they did in a letter sent to Gerberding last year, it is time for outsiders to pay attention.

The CDC's role in helping to assure public health has never been more important. Emerging infectious diseases such as SARS and avian influenza demand a rapid response, and epidemics of HIV and tuberculosis show few signs of abating. Obesity, heart disease and cancer end too many lives prematurely and demand authoritative and assertive management.

The CDC is not the only globally significant public-health organization whose performance is currently under scrutiny. Later this year, the World Health Organization (WHO) is due to elect a directorgeneral to succeed Lee Jong-wook, who died this summer. It is critically important that the WHO chooses a leader with the political and administrative skills needed to make the organization an even more effective player in addressing global public-health issues. Unfortunately, given the intrigue that often surrounds such contests, close observers of the WHO have scant
"When five former directors of the CDC feel compelled to intervene, as they did last year, it is time for outsiders to pay attention." grounds for optimism that this election will yield such a leader.

The Senate Finance Committee is already looking into alleged staff morale problems at the CDC, as well as the agency's use of funds that it has been asked to spend to counter bioterrorism. It is the duty of congressional committees to ensure that the agency and its money are being competently managed. Scientific bodies such as the National Academies could also be asked to play a role in monitoring the CDC's well-being. They should welcome any opportunity to do so, to help ensure that the agency maintains its proud tradition as an effective champion of public health, at home and abroad.

\section{Libya's travesty}

Six medical workers in Libya face execution. It is not too late for scientists to speak up on their behalf.

magine that five American nurses and a British doctor have been detained and tortured in a Libyan prison since 1999, and that a Libyan prosecutor called at the end of August for their execution by firing squad on trumped-up charges of deliberately contaminating more than 400 children with HIV in 1998. Meanwhile, the international community and its leaders sit by, spectators of a farce of a trial, leaving a handful of dedicated volunteer humanitarian lawyers and scientists to try to secure their release.

Implausible? That scenario, with the medics enduring prison conditions reminiscent of the film Midnight Express, is currently playing out in a Tripoli court, except that the nationalities of the medics are different. The nurses are from Bulgaria and the doctor is Palestinian (see page 254).

Despite the medics' plight, the United States agreed in May to reestablish diplomatic relations with Libya, 18 years after the bombing of an airliner over Lockerbie in Scotland that killed 270 civilians. Many observers had expected a resolution of the medics' case to be part of the deal. And the European Union has given Muammar 
Gaddafi, the Libyan leader, red-carpet treatment at the European Commission in Brussels.

International diplomacy, dealing as it does with geopolitical and economic realpolitik, by necessity often involves turning a blind eye. But its lack of progress in response to the medics' case in Libya is an affront to the basic democratic principles that the United States and the European Union espouse. Diplomacy has lamentably failed to deliver.

The principles of law and science have the common aim of discovering the truth. A previous assessment of the case by two prominent AIDS researchers, Luc Montagnier and Vittorio Colizzi, concluded that the charges are false, that the medics are innocent, and that the infections resulted from poor hygiene in Libyas hospitals. It was not a plot orchestrated by the CIA and Israel's Mossad, as President Gaddafi alleged in 2001 - an allegation that has driven a popular thirst for vengeance in Libya.

The case is politically embarrassing for Gaddafi. Finding a scapegoat is easier than having to admit that the infection of the children was an accidental tragedy. But the most likely diplomatic compromise - that the medics will be condemned to death, with this being commuted to a life sentence - is unacceptable. They are innocent, and the law and science can prove it, if they get the belated opportunity.
That is why scientists should lend their full support to the call by Lawyers without Borders - a volunteer organization that last year helped win the freedom of Amina Lawal, who had been sentenced to death in Nigeria for having a child outside marriage - that Libya's courts should order a fully independent, international scientific assessment of how the children were contaminated.

In 2004, an Editorial in this journal stated, with respect to the medics' case, that " $\mathrm{Gaddafi}$ has a chance to show the world that he now understands that true leadership means embracing justice, compassion and a respect for scientific evidence" (Nature 430, 277; 2004). Two years on, we are still waiting, and Lawyers without Borders is right to hold President Gaddafi and the international community to account.

The scientific community has also been relatively silent on the case, perhaps in the hope that it would be sorted out by diplomacy. But the latter has not proved to be the case, and scientific leaders need to use all their influence urgently, as the fate of the medics will be sealed in the coming weeks. It is time not only to save the doctor and nurses, but also to defend a common vision of science and law in establishing the truth, above all other imperatives. Meanwhile, Gaddafi has the opportunity to put this affair behind him by giving the six an immediate pardon.

\section{The brief goodbye}

\section{Because of trends in submissions, Nature's Brief Communications will bow out at the end of the year.}

$\square$ rom time to time these pages have proudly announced the birth of new sections of Nature and new research journals. Rarely, if ever, have we proclaimed a death. It is with mixed feelings that we now announce the demise of Brief Communications, whose final appearance will be in the last issue of 2006. Importantly, we will continue to give full support to Brief Communications Arising, an online-only section in which we publish critical discussions of Nature papers.

The Brief Communications section has provided a bridge between the journalism and opinionated sections of Nature and the review articles and full-scale research papers. The sections' intentions have been to capture the excitement and appeal of both - and in doing so has ensured plenty of impact both among readers and in the media.

There have been tales of rat robots, Neolithic noodles, nano-bulls, a cloned cat (as well as a more notorious cloned dog), of goings-on at the Moon's north pole and with the Queen's vowels, and there have even been models to unravel the best way of tying shoelaces, to list just a few. In generally no more than a single page, papers in the section have offered glimpses into breaking scientific news - including the giant Indonesian earthquake, SARS and bird flu, and on surprising climate effects of shutting down air traffic for three days after the attacks of 11 September 2001. All were underpinned by rigorous peer review, and the success of Brief Communications owes much to our referees entering into the often quirky spirit of the section without compromising Nature's standards.
The section has had its critics. Sober scientists have worried that such brief candles have diminished the stellar luminescence of the Nature references in their CVs. False rumours that the section was not peer reviewed have occasionally circulated. But Nature has stood by its short masterpieces, quirkiness and all.

Why, then, abandon this popular part of the journal, which continues to receive many more submissions than it can possibly publish? It is, we believe, an appropriate response to what we are increasingly receiving, and a belief that the pages can therefore be better deployed. Fewer and fewer submissions to Brief Communications have been making the grade - perhaps constrained by the short format and limited online supplementary material, they may be too lightweight, too technical, too long or too preliminary.

Perhaps today's pressures are forcing science to become more earnest and "Perhaps today's
pressures are forcing
science to become
more earnest and
more specialized." more specialized, as well as demanding greater detail in presentation. Never mind that Watson and Crick's paper on the structure of DNA was the length of a Brief Communication.

The section's demise will not affect the Brief Communications appearing in Nature research journals, where there is undoubtedly a place for short accounts for a more specialized audience. Moreover, Nature will, if anything, increase its support for Brief Communications Arising, in which critics of our papers can vent their views, usually with authors' responses.

We also remain committed to another virtue embodied in Brief Communications: being brief. The quality of papers can supposedly be enhanced by boundless web space; length is no longer such an issue. But our authors should be warned, and our readers reassured, that Nature remains a champion of succinctness. 